\title{
Farm Labor Monopsony: Farm Business And The Child Hierarchical Model Of Fertility
}

Douglas B. Reynolds, University of Alaska Fairbanks, USA

\begin{abstract}
Arthur Lewis (1954) classic article on duel labor markets suggests that subsistence labor, due to high fertility and overpopulation, causes low wages. Basu (1999) and Dessy (2000) show a compelling theory for high fertility in developing countries where regions go into a poverty trap of low labor demand, low wages and overpopulation. An alternative explanation for overpopulation has to do with a simple farm business model where farming families have a labor monopsony for their own child labor. Child labor, not from society at large but from the farm family's own children, can be a source of labor to run a farm business. The farm business model shows how, due to simple monopsony characteristics, it may be cheaper for a farmer to use fertility induced, family child labor, rather than expensive non-family labor, to provide his labor supply and increase his rent. Children can provide the farmer with labor that has a psychological barrier to exit, making it easy to add human capital without paying a high wage. However, due to sibling rivalry and child psychological growth stages of binding, delegating and expelling, older children will be forced to leave the farm inducing greater fertility to replace them. We assume capital investment options and the use of technology are limited for such farms due to monsoon rainy seasons, dense forests or steep hills, which suggests the need for labor intensive farms. The end result is that child labor is a way to provide significant profit to a farm business.
\end{abstract}

Keywords: Child Labor; Monopsony; Farm Business; Overpopulation

\section{INTRODUCTION}

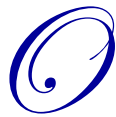

ne unique contribution to the economic development literature is Lewis' (1954) idea of two basic labor sectors: 1.) the highly populated, low productive, informal labor sector, and 2.) the low populated, high productive, capital intensive, formal labor sector. These two sectors separate developed countries from undeveloped countries, but can be found within countries. For example, Mexico City has a well-off formal sector even as an underclass of informal, poverty stricken workers live and work nearby. The city of Los Angeles also has many well-off workers, but where ghettos of almost subsistence workers exist nearby.

Gollin (2014) suggests that the Lewis model appropriately frames the question of development in terms of the duel sectors. Ray (1998) and Eswaran and Kotwal (1993) give interesting versions of the duel economy, although Basu (1999) offers a critique of Lewis' internal consistency. Nevertheless, the issue Lewis discerns is that there must be a source of labor that "over-crowds" the labor supply market, and as Lewis says where, "frequently this number could be halved without reducing output in this sector." This suggests that the return to capital should be high in the subsistence sector, and yet there is some sort of impediment to the flow of capital from the capital rich sector to the subsistence sector. Likewise, there may be an impediment of labor flow from the subsistence sector to the capital sector, although as Mexico City and Los Angeles show, there are indeed many workers migrating from low, subsistence-wage regions into high wage regions.

In this article, we look at the economics of poor subsistence farming where Kirkpatrick and Barrientos (2004) and Colman and Nixson (1994) suggest that the farmer controls a specific plot of land and manages it. Therefore, the small plot of farmland can be considered a business that needs labor and capital inputs. Often, though, it is impossible for developing farmers to be able to use capital machinery due to the local environment, such as steep 
hills, heavy monsoon rains or dense forests, and therefore, the farmer is forced to maximize his farm's value using labor rather than capital, and fertility is a source of cheap, relatively high-skilled, labor, seeing as children on farms receive intense training and human capital development but where there is a significant barrier to exit. This creates a monopsony.

However, there is one problem with the high fertility labor supply option, as the psychology literature attests, which is that children change psychologically as they grow up. As every parent knows, children have their own, very powerful utility functions in regard to money and power. Furthermore, these powerful, parent-child interactions are not constant over time because a child's utility function changes, unlike an adult's utility function which tends to be constant. Therefore, a child's utility function is dynamic and goes through a set of changes culminating in what might be called "metamorphosis," and which must be accounted for. We model an example here. The model shows how the oldest child can change his utility function and therefore cause a change in the wage and labor market dynamics within the family's hierarchical monopsony. This psychological change then forces the farmer to have the oldest child leave the farm, whereupon that child is replaced by a younger, more compliant child through fertility. This family dynamic is the cause of a continuous need for high fertility on the farm and indeed a cause of increases in the labor supply of the region and increases in population.

\section{THE ENGINEERING LIMITS TO TECHNOLOGY}

Lewis suggests one key to understanding the subsistence labor market is to look at the ability of capital to move, or not move, into the subsistence sector, which is called "lumpiness," i.e. some locations have capital while others do not. Wang and Piesse (2013) suggest the lack of movement of capital into the informal sectors is, "because (those sectors) have different objectives and organizational models." It is possible, though, that rather than the mobility of capital being constrained by financial or business factors, such as a lack of micro-loans, capital mobility is constrained by engineering factors.

Isn't it amazing that if you observe many developing country farm locations the subsistence agriculture is often not amenable to using modern capital machinery. For example, Egyptian farmers used to have their farm lands flooded in the spring by the Nile River, which gave nutrients to the soil and gave water for the crops but where the waterengorged, muddy fields could not support a tractor or a large mechanical plow or harvester. In Indonesia, many farm lands are terraced along steep hillsides where rice is gown in small, level patties, but where few tractors or machines can make it up those hills. In India, Malaysia, and much of South East Asia rice patties are under water especially during the monsoon season, which increases the effectiveness of growing the rice, but which again makes it impossible for any kind of tractor or harvester to make its way through the muddy waters. In Mexico, corn fields are intermingled on steep hillsides. The corn husks and stocks and some of the dense forests are burned to create a sort of fertilizer for new crops but where the soil becomes loose and gives way easily during the rainy season if tractors go over it.

In contrast, the automation of agriculture in the U.S. is characterized by large-scale mono-agriculture where only one thing is done at a time such as growing wheat on large fields with large harvesters or raising hogs in large buildings with huge feed conveyor belts. This difference in the amenability of capital to induce productivity may be the reason why there are different labor market equilibriums. In contrast, Basu (1999) and Basu and Van Pham (1998) show different labor market equilibriums caused by low demand side purchasing power which keeps the productivity of labor low and wages low. Dessy (2000) shows a possible "poverty trap" or "subsistence ghetto" characterized by mostly child labor and low wage rates and where technology is kept out only because of a lack of a good business environment. However, if technology and capital are constrained by the physics of the natural environment rather than due to business and financial considerations, then we need to re-evaluate the labor dynamics of farms as businesses, which can create overpopulation and high fertility.

\section{THE PROBLEM OF LABOR MOBILITY}

If we assume engineering constrains capital mobility on subsistence farms, then we have to look at labor markets. According to Bewley (1999) and Boal and Ransom (1997), almost every individual firm, even a developing country farm, which is also considered to be a firm, has labor market wage rigidities and barriers to entry that make it very 
difficult to have easy labor mobility and flexible wages. Indeed, barriers to labor mobility are pervasive in all economies. In that case, hiring labor is costly due to training costs, hiring costs and mobility costs. For example, a relatively skilled farm worker must be paid a high enough wage to induce him to stay on that farm and continue to work there, while an unskilled worker must be paid for training and then once trained, paid to stay. Manning (2003) suggests that paying someone to stay and work for you constitutes mobility costs, which would also include the expected probability for the new worker to be unemployed. Therefore, economists assume firms pay what is called an efficiency wage in order to keep the worker from leaving. However, team-work is best induced when everyone gets very close to the same wage, so not only is a farmer forced to pay extra to train and keep new workers, the efficiency wage, he is also forced to pay extra to all his existing workers to keep them happy. This creates pervasive monopsony situation.

Such monopsony situations on labor intensive farms means that any lease holding farmer would endure quite a bit of labor mobility with workers continually moving from one farm to another in search of better opportunities. Yet in realty there just isn't a lot of labor mobility in poor rural regions, other than laborers migrating to cities for work. This suggests a different labor market model entirely.

\section{THE BASIC MONOPSONY AND HIERARCHICAL MODEL}

Becker (1988) shows that one source of labor supply for developing country farms is high fertility, and according to Becker (1960), Becker (1981) and Becker and Barro (1988) a parent's utility is a determining factor of that fertility. Applying this to a farm, Rosenzweig (1977) shows how utility can induce families to be large, but with an assumption that the fertility will reach a limit where utility is maximized. However, it is also possible to show how utility is never fully maximized due to the inherent instability of the family labor system, creating a need for ever greater fertility.

Another interesting set of literature is Neher's (1971) and Liebenstein's (1957) idea where there is a game theoretic play between the wife and husband about maximizing each of their individual values to have children. Also Buchanan (1987), Cigno (1993, 2005, 2006), Rosati (1996), Cigno and Rosati (2005), Stark (1993) explain how a family constitution can model fertility where the entire family is beholden to a family constitution that is seen as maximizing intergenerational value. Basu (1999) and Dessy (2000) also suggest that the explanation for the impediment of the flow of capital to subsistence regions is that these regions create their own islands of low demand for labor where low consumer demand causes a self perpetuating low demand labor market that is difficult to change.

However, while the Becker and Rosenzweig utility functions include the utility of the children from the perspective of their net present value of earnings and how those earnings create utility for the parent, an alternative assumption is that the parents' utility function is simply a non-altruistic, wealth maximization utility function, but that it must interact with a child's changing utility function. The farm, then, is simply a profit maximizing firm, where one reason to have children is as a pure labor supply source. However, not only do children produce crops and maintain the farm (create profit), they are also handy for providing parents with cooking and cleaning services (create services), not to mention entertainment, and the children have low subsistence wages, made even lower due to economies of scale in food, shelter and clothing costs, where everything is shared. The psychological cost of managing and administering one's own children to work hard and to do things correctly can also be low in comparison with the psychological costs of managing non-family workers.

Consider, then, a farmer with two options: 1.) hiring an outside worker or 2.) having his own child work for him. Children are excellent workers. It can be easier to match a worker to a job where you know that worker well, such is your own child, then to match a worker to a job when you do not know the worker well such as a non-family worker. Plus, the farmer has absolute authority over his children and can put the child to work in difficult situations and keep all the rent of the child's labor for himself with impunity. The farmer does not need high wages to attract labor, as the labor supply is based on his own fertility. The family farm is immune to external wage structures and lost opportunity costs of training as children tend to stay put, i.e. the farmer's workers, his children, have a significant barrier to exit due to familial psychology. While it can take a few years to produce each worker-child, eventually there will be plenty of labor, which grows in experience, strength and acumen. 
Children can obtain the motivational effects of an efficiency wage merely by psychological means. For example a parent giving compliments or scolding can motivate a child effectively. Such psychological motivation methods, including learned helplessness, would not work well for non-family workers. With family workers there is also a sense that any effort given goes to the general wellbeing of the family and poor workmanship hurts the general wellbeing of the family. Children therefore, are automatically in a team-work situation and are therefore highly motivated to work well compared to non-family workers, who perceive that all their efforts are rewarding someone else. Brothers or sisters in a family are also highly motivated to give compliments to each other or to point out each other's bad workmanship. Non-family workers are not easily amenable to such psychological motivations. Plus if children receive a small allowance or a small reward, such as a toy, then that keeps them highly motivated with little salary involved. Indeed, what is most beneficial for the farm as a business is that farmers do not have to reward each child based on their productivity, but can reward them based on their age, and still keep them highly motivated. For example each year older a child becomes allows them to attain a higher seating position at the dinner table.

Another advantage of child labor is being able to match jobs on the farm to a child's natural potential talents: strength, dexterity, capacity for knowledge, empathy, emotional balance, fearlessness, sensitivity to smell, sight, hearing, speed, endurance and such. Then, the advantage of matching the perfect child to the perfect job is solidified by training, experience and pointers from the parents. Every child is integrated into a true team of professionals, although, the children don't know it. Religion, family traditions and culture further mold the family unit into a highly capable and integrated "division."

The costs of training are equally low for children. Most infants are carried by their mothers while the mother works in the fields, and so infants do not require a lot of cost. The infants then have a chance to watch much of the work that goes on. Toddlers are often allowed to play "work" on location and also watch the work as it happens and to try it out just for "fun." Grandparents can be used to teach certain skills and lessons for children while the parents work. So the hiring costs are low and the cost to keep a child for its first five years, before they start doing chores and work around the farm, is low due to the minimal subsistence needs of small children and the economies of scale of eating the same food as everyone else and sleeping in the same beds as everyone else and wearing the same hand-me-down clothes as everyone else. Truly, children are cheap.

To see the difference between a farm that has to hire non-family workers and a farm with child labor, consider Figure 1, which is explained in mathematical terms in Appendix 1. Figure 1 shows what a farmer must do to hire outside laborers. The labor supply, Lsupply, is a normal economic labor supply curve for a region where the higher the wage, the more workers are available to the farmer because even a small farm in an overpopulated region must pay an efficiency wage to attract and keep semi-skilled labor. However, due to Bewley's (1999) idea of team work, the farmer is forced to pay existing workers just as much as any new workers, and therefore, the marginal labor costs are above Lsupply. Due to this pervasive monopsony, the farmers demand for labor is not Ldemand but the marginal labor cost. Although the monopsonist gets a high productive value, $\mathrm{V}_{1}$, at a low average wage, $\mathrm{W}_{1}$, and a high rent, $\mathrm{R}_{1}$, which is the area below the demand curve and above the supply curve, nevertheless, this limits the number of laborers hired to $\mathrm{L}_{1}$ laborers. 
Figure 1. A Monopsony Model

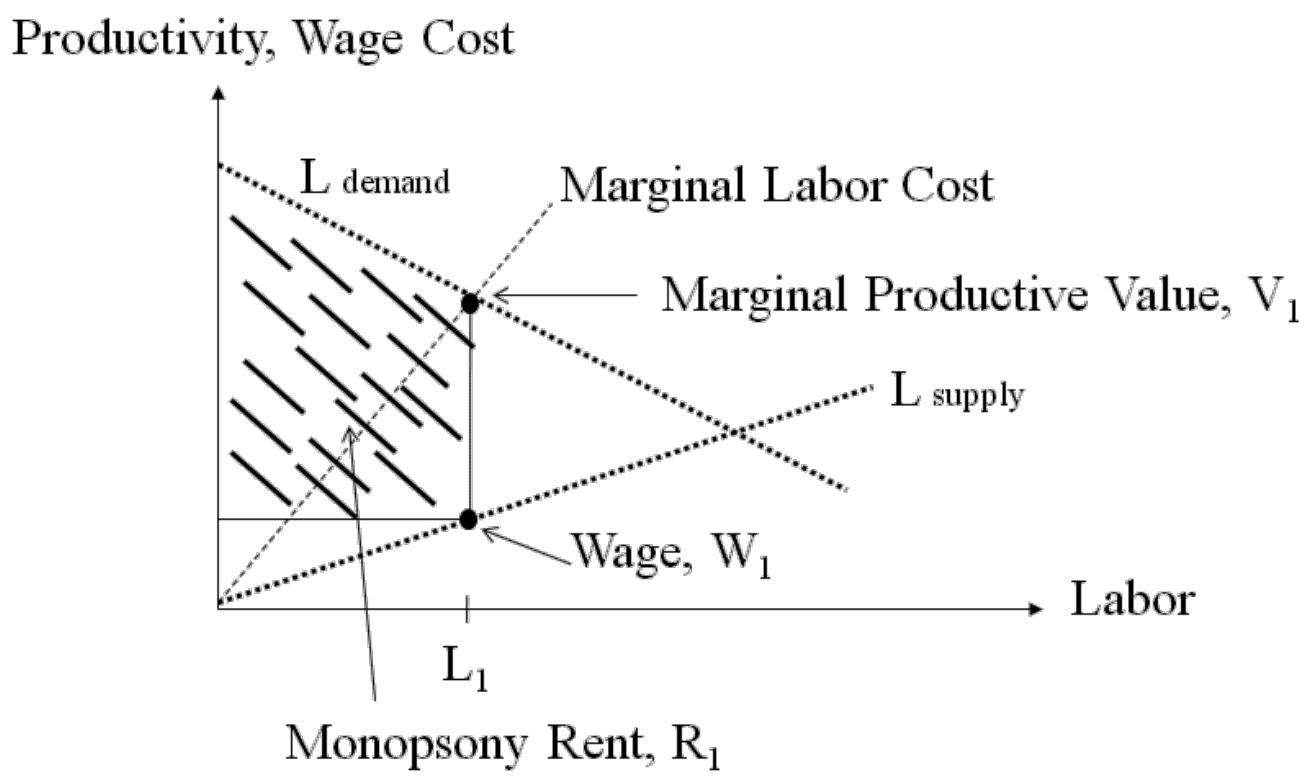

In the normal Monopsony model, in order to bring in new labor supply, the manager has to provide higher wages to all existing workers in order to keep the peace. That makes the marginal labor cost much steeper than a normal labor supply curve, even though the final wage paid is much lower than the value.

The reason there is such a large effect on other workers' wages is because there is internal communication about each workers' wage. The best way to keep a sense of fairness, to keep a sense of team-work, and to keep all workers highly motivated is to make sure everyone gets about the same wage. This implies a normal monopsony model, where the employer is forced to raise all wages up to the level of the last or marginally hired worker.

\section{The Basic Hierarchical Model}

What if instead of a monopsony where the workers compare their wages, there was a strict hierarchy, where the workers had differentiated wages based solely on their age, but where wages were extremely low and yet where the motivation of each worker was extremely high, and where the workers honestly believed in the wage structure. A family with child workers could be such a place. Children do not know what an appropriate wage is and so are willing to work for a low wage that a grownup will not work for. Children are psycho-socially easy to motivate and sometimes have skills with small hands that adults do not have. The children workers will all help each other learn the necessary skills. Investment in human capital in the form of on the job training will not be wasted on a farmers own children, who will stay at the farm for many years-i.e. children have barriers to exit.

Consider, then, a strict age-related, family wage, where each worker is paid a slight increase for each year older they are in Figure 2, also shown mathematically in Appendix 1. What Figure 2 implies is that there are incrementally, diminutively higher wages for each child worker, not based on productivity, but based purely on their age. However due to psychological family dynamics, each worker is still highly motivated. Yet, because of the low cost for workers, the farmer has the incentive to hire (have children) up to the point where the marginal productivity equals the wage cost of the last or marginal worker at $\mathrm{L}_{2}$. That is, the farmer makes more money using fertility because he can have more workers at a low cost. His rent is the family rent $\mathrm{R}_{2}$, which is the value the farmer receives for all his child workers. This implies the parents receive all of the rent of the farming plot of land and that they do not give anything to the children. 
Figure 2. A Hierarchical Model

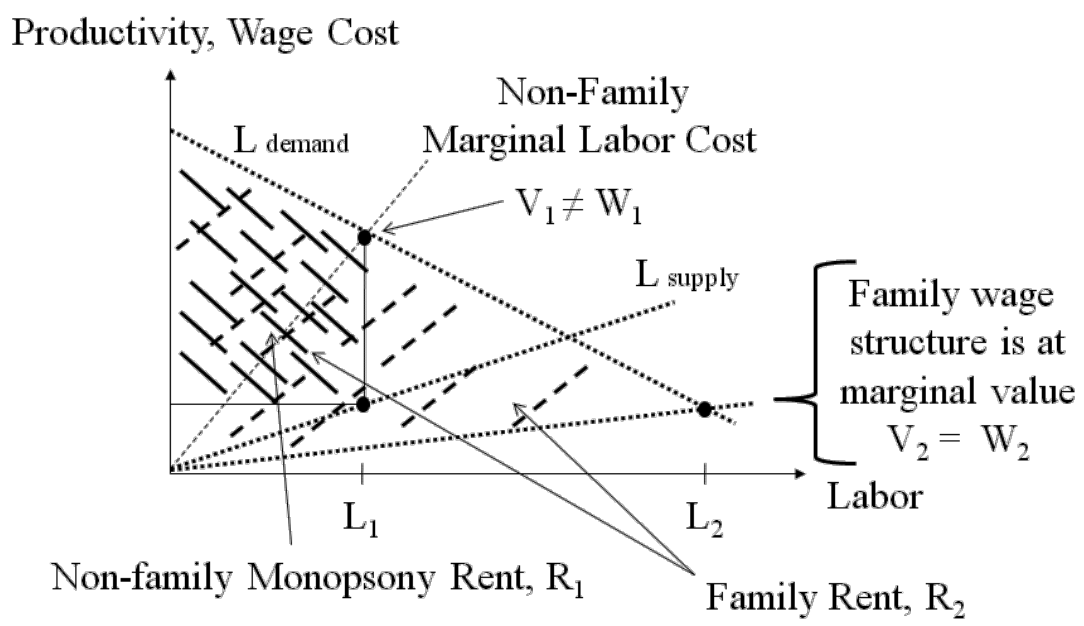

Unlike the normal Monopsony model, the Hierarchical model has a supply curve that is equal to labor costs. Each new hire, the next child, has a low wage that is independent of the other laborers' wage, as each family member is given a small incremental benefit based on their age and which is independent of productivity.

One reason for a farmer to want to keep all the labor rent, the farms profit, for himself and not give any of it away to his children, such as in the form of paying for their education or giving them lump sum payments, is due to risk aversion. Risk aversion is often an important part of a utility function that is difficult to model. According to the risk aversion literature, such as Stoner (1961), Kogan and Wallach (1964), Sorrentino et. al. (2005), Kowert and Hermann (1997), and Kahneman and Tversky's (2002), if a farmer is risk averse, he may well tend to keep most, if not all, of the farm's income for himself and his current, farm working, children due to the possibility of catastrophe. This does not imply that a parent is not altruistic, in the sense of Becker, Rosenzweig, Basu and Dessy where the farmer would want to give at least some of his rent to his children in the form of education and other benefits, rather it can simply imply that parents keep the farm's rent for themselves in case of catastrophic weather or other destructive events, which is often the case in developing countries. Therefore, we make the simplifying assumption that parents are wealth maximizing for themselves and their home bound children. Later, that assumption can be amended due to the psychological change of the oldest child.

Interestingly, Figure 2 still implies that the farmer does not want as many children as physically possible, because the wage of the last child, even if it is a subsistence wage close to a zero, could be above the marginal productivity. That is, it is possible to have too many worker children where the extra subsistence wage is greater than the marginal productivity causing lower profits for all. Therefore, the farmer may want to refrain from having too many kids along the lines of Becker and Rosenzweig. In that case, the farm parents would naturally want to have family planning and limit the size of the family at some point. Unfortunately, the farmer must deal with another factor that may determine fertility: a child's changing psychology.

\section{THE UTILITY FUNCTION OF CHILDREN: AN ENEMY IN THE CAMP}

Becker, Becker and Barro, and Rosenzweig show how a parent's utility, along with a child's net present value of lifetime work can be a cause of fertility decisions. Sen (1966), Kirkpatrick and Barrientos, and Colman and Nixson assume the rent on the farm is equitably distributed to all family members. However, if the utility of the farmer includes the parent's gain in value from the work of the children, then according to Ahrens (2003), if a parent can attain a higher income by having more children, then that can induce high fertility. However, children also have a utility function to consider, which may also affect a parents' fertility decisions. 


\section{Child Metamorphose}

In the psychological literature, Stierlin (1994) shows considerable psychological evidence that suggests an evolving, dynamic parent-child interaction within each family where children have strong psychological desires and needs of their own, which in turn suggests there is a game theoretic situation between parents and children. Stierling shows how a parent-child interaction in a family follows a strong pattern of progression including the psychological stages of binding, delegating and expelling. These natural psychological processes necessitate that the farm family's business management interactions take account of a child's changing utility. For example, during the transitional stage of binding, a baby, a toddler or a small child understands the outside world as a hostile and foreboding place where the only safe place to be is with the parents. Only within the family is there security and satisfaction. This is a stage that tends to occur early in childhood and it is a natural way for parents and children to bond together in order to strengthen the parents desire to help the child survive. This also naturally helps keep children from wondering away from parents and induces children to run to their parents when there is danger. It can also create learned helplessness, which naturally creates a labor barrier to exit, perfect for keeping child laborers' human capital on your farm.

Next, there is the transitional stage of delegating. In this stage, the child becomes a delegate of the parent. The parent sends the child out to see new things and find out what is outside of the immediate family orbit, although with the explicit understanding that the child will come back. This stage is where the child learns a craft and undertakes new job duties but still is inclined to stay close to home and family. The child, while he can learn many skills and work productively, is still ignorant of the wider world's opportunities, wages and economic structure; and the child, more or less, does what he is told to do without question, or a demand for wages. The central key to this phase is that of following the directions of the parent while learning new skills and knowledge.

Finally, there is the most disruptive stage of all, that of expelling the child, although, in reality, it is the child that expels the parents. In this phase, the child undergoes what can be called "a metamorphosis." The metamorphosis of the child creates a crisis in the family, where the child is seen as a hindrance to the normal day-to-day operations of the family function, what many might call the rebellious teenage years. This is where the child is naturally interested in new people outside of the family, new ideas and new knowledge but at a much higher level than during the delegating phase. It is in this phase where the child finally comes to an understanding of himself as a separate entity different from his parents, and he questions the parents' authority. He also realizes the economic value of work and that others in different farms and firms are getting paid a wage. He comes to the realization that the parents are unfairly taking advantage of him by taking all his work's value (his rent) and keeping the rent for themselves. Furthermore, this is the phase where a child turns into an adult and desires his own family, a very powerful change in his utility function. Indeed, right around the late teenage years, there are profound changes in children, and this suggests that there are three utility functions interacting and affecting family economics: the utility of the parents, the utility of the young children and the new, emerging utility of the oldest child after metamorphosis.

After metamorphosis, the child may realize he is being exploited, and therefore the oldest child will now demand compensation for his work. This crisis, then, requires a negotiation between the parent farmer and the child laborer to divide the farm's rent.

\section{Sibling Rivalry and the Crisis of Discontent}

The utility function of a family is not one simple story, but rather a complex interaction that is bigger than the relationship between the oldest child and the parents, for there are also very intense relationships going on between the young siblings as well. Handel (1994) explains that children who have not undergone metamorphosis have an idealized brotherhood and sisterhood between themselves where they are able to work together with equality, solidarity and unity. However, there is also "sibling rivalry." A light, sibling rivalry occurs between kids where each child tries to finish first or do more, which helps spur on productivity and moral, even as there is a sense of camaraderie within the rivalry. The very delicate balance between sibling rivalry and sibling camaraderie is enhanced by a sense that parents treat each of the siblings exactly equal. This is crucial. For if even one iota of difference of reward between the siblings is observed, other than a simple age bonus difference, then the delicate 
balance between sibling rivalry and sibling camaraderie can be undermined. This implies that there is not one, not two, but three basic utility functions interacting with game theoretic ferocity within the farmer's family: 1) the parent's utility, 2) the young children's utility before metamorphosis, and 3) the oldest child's utility after metamorphosis.

During the crisis of the oldest child, when he or she goes through a metamorphosis, there is suddenly a break in all camaraderie and harmony between the siblings such that intense rivalry and disharmony emerges, especially if the parents do not continue to treat the siblings as equals. Every parent and sibling understands the vital importance of equality of treatment as a pervasive characteristic of a harmonious family. If this equality is in any way changed or disrupted, then there becomes a more intense destructive sibling rivalry in a fierce competition for scarce resources and parental attention. There is no bigger symbol of rivalry and inequality than that one child should be given monetary compensation, above a simple age related reward, for work on the farm while the others are not given such compensation.

Therefore, if the oldest child, who has gone through metamorphosis and may want to start his own family, wants to receive a wage for his work, then this will affect his siblings' feelings. Suddenly siblings will realize a severe inequality and lack of brotherhood within the family. This does not imply that the other, young children are going through their own metamorphosis, rather it implies that the balance between sibling rivalry and camaraderie that the parents have painfully built is in danger of being destroyed if the oldest child gets paid. The siblings will see a loss of the family rent in the form of food and shelter that they would normally receive for themselves going to the oldest child. If the oldest child suddenly gets paid, the other children will assume there is not enough money to feed them. Therefore, each younger sibling, who is still in the delegating phase of childhood development, will want an increase in pay to compensate for the unevenness of paying the oldest child. This creates a huge marginal cost, a monopsonistic marginal cost, for the parents.

Therefore, the theory of the family farm follows four characteristic. First, the parents keep all the rent of the farm for themselves due to risk aversion and use fertility to obtain child labor. Second, the parents pay a subsistence wage to all their children with only an age related perk. Third, the parents are confronted with the once compliant oldest child, who suddenly becomes a wage demanding adult, which affects the parents' relationship with that one oldest child. Fourth, and more dangerous to the family's economics, the oldest child's demand for a wage starts to affect the other siblings due to sibling rivalry. If one child receives pay, then that one child is being treated differently from the other siblings, which disrupts the harmony of the other children working contentedly at a low pay. This causes the family business operations to come into peril, and this crisis has to be dealt with swiftly and with severity or else it will inflame into a broader family crisis. The answer to this problem is that the oldest child must leave.

\section{A MONETARY EXAMPLE OF A METAMORPHOSIS}

Let us consider a simple hierarchal, farm model, where the oldest child goes through metamorphosis and goes from being a compliant-worker to a non-compliant wage negotiator due to the psychological transition of changing from a child to an adult. Unlike, Fei and Ranis (1964, 1997), Fields (2004) and Sens where the children's wages are equal to average productivity, here we assume the wage of the child-worker is equal to the marginal subsistence cost of feeding the child plus a small token for being older. The metamorphosis, though, disturbs the overarching family dynamic of sibling fairness and equality as suddenly the oldest child wants a substantial wage increase and not just a token wage.

Assume that the productivity of each new child laborer follows the law of diminishing returns to the number of workers, i.e. there is no age related productivity of each child laborer. Figure 3 shows such a productivity schedule: 
Figure 3. The Farm's Marginal Productivity Curve

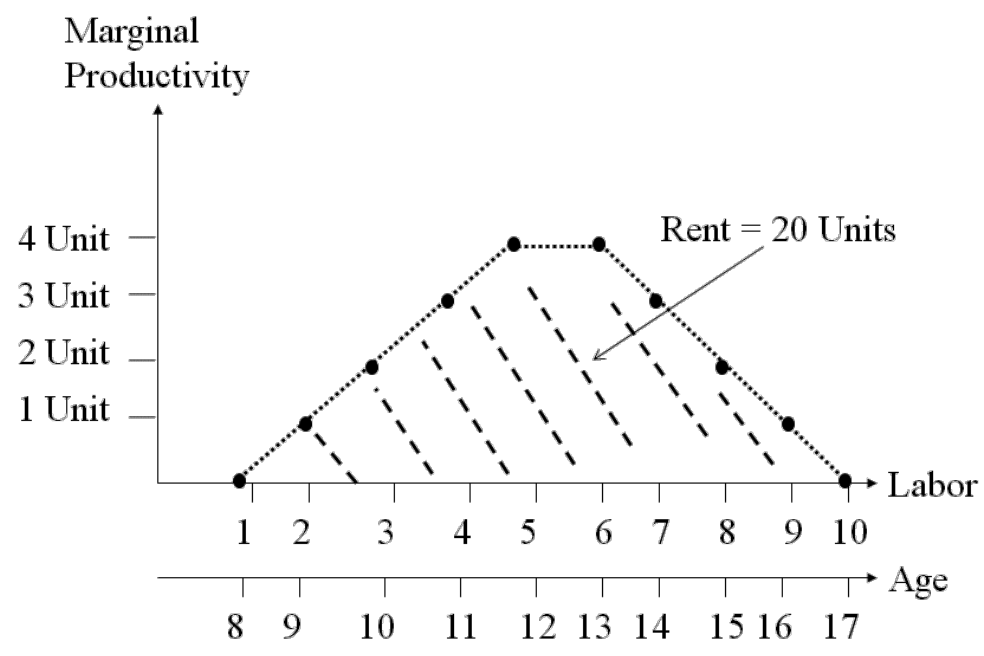

The productivity of each additional worker is shown. It is assumed that only the farmer's children work on the farm and so the age of each worker is shown. However, the productivity is not based on the age of the worker, rather it is based on the number of workers, but the age is shown for completeness.

Figure 3 shows children starting work at age 8 when each child is old enough to undertake meaningful tasks. Productivity, though, follows the law of diminishing returns with respect to the number of workers, not necessarily the age of the workers. A change in age will normally add productivity to each worker, but here we assume that the more important productivity input is the number of children not the age of the children. For example, if there are two children working to fix a fence, the older child will know how to fix it, but the younger child can run and get tools and equipment that adds much value to the older child's work effort. Working together they accomplish more than if they were to work separately, so it is unclear if the marginal productivity should be awarded to the older worker who knows a lot or the younger worker who gives the older child more time to concentrate on the job. Both are necessary. Here we simply assume that worker numbers relate the most accurately to marginal productivity rather than experience.

In this instance, the farmer wants 10 children in order to maximize his farm's profit (rent) as the marginal cost of each child is close to zero units. Furthermore, when the farm is first started, in order to maximize the present value of profits, the farmer needs to have one child every year so that he can buildup his labor force as fast as possible. Normally the farmer would just have the 10 children and then stop having children, whereupon the age of each child will increase and eventually become productive by age 8 . Then the children would stay and work on the farm for many years, or forever, with little or no pay. However, consider what happens when the oldest child experiences metamorphosis.

Once the oldest child is say 17 , and with the ten siblings already working, his average productivity is 2 units, which is the total rent of all the child workers divided by the number of child workers, i.e. 20 units/ $10=2$ units. The oldest child realizes he is being exploited by his parents and he goes to his parents and asks for a wage of 1 unit, which is less than the average productivity of 2 units, and therefore it seems a fair wage to the oldest child. Nevertheless, the marginal productivity of the oldest worker is actually zero, not because he is more or less productive than any of the other children, but simply because he can be considered the last or marginal worker to be on the farm, i.e. the tenth worker. By the time the oldest child is 17 , other children will have many of the same skills that he does. If the oldest child were to be gone for some reason, all the other children would be able to rearrange their work assignments to compensate for the loss of the oldest child and total output would not be affected.

Assume, then, that the parents know that the oldest child's marginal value is actually zero and that it is easy to reconfigure the work force to replace the oldest child. The parents also would know that if they pay the oldest child a real wage of 1 unit, then the balance between sibling rivalry and camaraderie of the other children will be 
destroyed and that the other siblings will then all want more pay in order to regain that balance. The parents are also looking at a decline in the moral of the child work force if they pay the oldest child a wage.

Nevertheless, the oldest child, will realize that other non-family workers on other farms are getting paid a wage and he will want a portion of his value especially since he may also be considering having a family of his own. However, if the oldest child demands a pay of 1 unit, then, because of sibling rivalry, this may cause at least three or maybe more of the next older children to want their own pay raise or they will perceive inequality or even the possibility of less food and less clothing for themselves or the family. This is the crisis. Suddenly the parents are looking at a loss of not just 1 unit of pay for the oldest child, but four or more units of pay to many of the siblings in order to restore the sibling rivalry and camaraderie balance. If the parents are forced to pay four units of value to keep the peace, then the marginal cost of the one disgruntled child is a $20 \%$ loss in rent, if all the siblings want a pay raise, then there is a $50 \%$ loss in rent. This would be unacceptable.

\section{The Family Crisis Solution}

There is a simple solution to the crisis: send the oldest child away. If the parents send the oldest child away, then they do not have to pay the oldest child the 1 unit of pay, nor pay the other children any monetary compensation, and there will be harmony between the siblings. Plus the parents will still have enough workers left to keep the same productivity and so lose nothing economically. The farmer simply replaces the oldest child with another new, young child through fertility. Indeed, the parents can have a plan: as each child ages into their late teenage years, they leave the family in sequence. Then the parents will have a new baby child in waiting to replace the old child. Better to have the oldest child leave the family quickly and quietly and have a new child replace him for nothing then to have to pay the oldest child 1 unit of pay and then to have to pay the next three or more children what they require to keep the peaceful balance between sibling rivalry and camaraderie. This is a classic monopsony problem.

Therefore, the parents must change the oldest child's focus away from negotiating a wage and toward knowing that he must leave the family and make his own way in the world. What is more, there can be a tradition of older children leaving the family at the critical, metamorphosis age. For example, a simple fairy tale story like Saint George and the Dragon can be used to induce the child to leave. One version of that story is where a knight leaves on a long journey and fights a dragon to save a princess and inherits a kingdom. Such a story is the perfect, intoxicating tale to induce an older male child to leave. An older girl child may be simply given away in marriage, although in order to make sure someone takes the daughter, a dowry can be provided. In essence, the family farm becomes an assembly line of child-laborers. The oldest child is paid-off to leave, or simply sent away. New births are meant to eventually replace older adult children as they go through their metamorphosis, have their family crisis and leave.

It is also possible to have one of the children, possibly the first male child, replace the parents on the farm. That replacement child will work for no pay until the day he takes over the farm. He will not mind the lack of pay, knowing that soon he will have the farm as his reward. Once he does take over, he will take care of the parents, who now become grandparents, and he will take care of the remaining on-farm siblings in the same hierarchical model as his parents did. The new farmer will allow his existing siblings to work on the farm until he can replace them in sequence with his own children. Again it is an assembly line transition. The original parents will still be there to give a sense of the old family, but the new adult-child farmer will also be starting to have his own children to take over the work in sequence as the adult siblings become old enough to leave.

\section{CONCLUSION}

In this article, we showed that a parent farmer can obtain valuable, low cost labor services using fertility. If the farmer hires non-family workers, he is forced to pay high efficiency wages to attract those workers, even when they live nearby, due to the need to pay for mobility costs, the possibility of unemployment or to keep the worker from leaving. If the farmer has children, though, he can obtain cheaper labor that relies on psychological motivations to work hard with very low wages. In addition, the farmer can accurately match the skills of his fertility induced child laborer to specific tasks on the farm and train the child to do exactly what is needed. Since the child is subject to learned helplessness, there is a barrier to exit, so that all the human capital training that is invested into the child will 
not be lost. Children do not have to be paid much, other than a perk to keep working, and their costs are low due to economies of scale of shared food, bedding and clothes. The farmer keeps all the rent of the child worker due to risk aversion of the farmer, where the farmer is concerned for his and his current children's wellbeing in the event of some sort of catastrophe.

Once the oldest child matures, though, he goes through a metamorphosis where he demands a portion of his rent producing work for himself so that he can start his own family. However, if the oldest child receives a wage, the other children will perceive unfair sibling rivalry and a lack of camaraderie and demand a wage as well. The solution is to force the oldest child to leave, possibly with a small sum of money, to make his way in the world. When there is economic development in a country and there exists labor intensive farms, then the family farm's fertility creates lots of labor supply for that country's industrial development. The more economic development there is, the easier it is to have the oldest child, or even younger, pre-metamorphosis children, leave as there would be lots of economic opportunities outside of the farm. Children, after their metamorphosis, may want to leave a family farm early in life in order to make more money elsewhere. It is even possible for parents to "sell" their children, or for parents to force their children to work elsewhere, if that is lucrative, or in the case of dire need, necessary. However, in order to continue to have enough workers on the farm, the farmer will want to keep having more children as fast as possible in order to compensate the loss of each older child worker that leaves. As these workers leave the farms in droves, and head to the city, the farm monopsony can be a source of much unskilled labor in the city to fuel the duel labor sectors of many developing cities.

\section{ACKNOWLEDGEMENTS}

Special thanks goes to Professor Greg Goering, without whose help this article would not have been possible.

Special thanks to University of Alaska Fairbanks Vice Chancellor for Research for funding for this article.

\section{AUTHOR BIOGRAPHY}

Douglas B. Reynolds is a Professor Economics in the School of Management at the University of Alaska Fairbanks (UAF), USA. He has worked, studied or researched economic issues in Kazakstan, Mexico, Norway, Russia and Poland. He has consulted on businesses and economic issues in Alaska and around the world. He has been an Economic Advisor to the North Slope Borough, Alaska, where he did inflation indexation, fiscal systems analysis and village utility economic analysis. He has over 70 academic and technical articles in energy and business fields as well as a book, Energy Civilization, which explores historical economies.

\section{REFERENCES}

Ahrens, W. Ashley (2003). “The Birds and the Bees (and Dollars and Cents): The Alaska PFD and Birth Rates,” Pacific Northwest Regional Economic Conference, Spokane, Washington, May.

Basu, Kaushik, (1999). "Child labor: Cause, consequence, and cure, with remarks on international labor standards," Journal of Economic Literature; September, Volume 37, Number 3; pp. 1083 - 1119. and Hoang Van Pham, (1998). "The economics of child labor," The American Economic Review, June, volume 88, number 3 pp. $412-427$.

Becker, Gary S. (1988). "Family Economics and Macro Behavior," American Economic Review, Volume 78, number 1, pp. 1 13.

, (1981), A Treatise on the Family, Cambridge, Mass. Harvard University Press.

, (1960). "An Economimc Analysis of Fertility," in A.J. Coale (ed.), Demographic and Economic Change in Developing Countries, Princeton, Princeton University Press.

and Robert J. Barro (1988), “A Reformulation of the Economic Theory of Fertility," Quarterly journal of Economics,

February, Volume 103, Issue 1, pp. 1- 25.

Bewley, Truman F. (1999). Why Wages Don't Fall During a Recession, Harvard University Press, Cambridge, MA.

Boal, William M. and Michael R. Ransom, (1997). Monopsony in the Labor Market, Journal of Economic Literature, Volume 35 , pp. $86-112$.

Buchanan, J. (1987). "Constitutional Economics," in The New Palgrave: A Dictionary of Economics, London, Macmillian. 
Cigno, Alessandro, (1993). "Intergenerational Transfers without Altruism: Family, Market and State," European Journal of Political Economy, Volume 7, pp. 505 -518. , (2005). "The Political Economy of Intergenerational Cooperation," in S.C. Kolm and J. Mercier Ythier (eds.), The Handbook of Giving, Reciprocity and Altruism, Handbooks in Economics series, ed. Keneth J. Arrow and M. D. Intriligator, Amsterdam: North-Holland. , (2006). "A Constitutional Theory of the Family," Journal of Population Economics, Volume 19, Number 2, pp. 259289.

and Furio C. Rosati, (2005). The Economics of Child Labor, Oxford University Press, Oxford, UK.

Colman, D. and Nixson, F. (1994). Economics of Change in Less Developed Countries, London, Harvester Wheatsheaf.

Dessy, Sylvain E. (2000). A defense of compulsive measures against child labor, Journal of Development Economics, Volume 62, pp. 261-275.

Eswaran, Mukesh, and Ashok Kotwal, (1993). “A Theory of Real Wage Growth in LDCs,” Journal of Development Economics, 42(2): 243-69.

Fei, J. C. H. and Ranis, G. (1997). Growth and Development from an Evolutionary Perspective, Oxford, Blackwell. (1964). Development of the Labor Surplus Economy: Theory and Policy, Homewood, IL, Richard A. Irwin.

Fields, G. S. (2004). 'Dualism in the Labor Market: a Perspective on the Lewis Model after Half a Century', The Manchester School, Volume 72, No. 6, pp. 724-735.

Gollin, Douglas, (2014). “The Lewis Model: A 60-Year Retrospective," Journal of Economic Perspectives, Volume 28, Number 3, Summer, Pp. 71-88.

Handel, Gerald (1994). "Central Issues in the Construction of Sibling Relationships," in Gerald Handel and Gail G. Whitchurch Editors, The Psychosocial Interior of the Family, $4^{\text {th }}$ Edition, Aldine de Gruyter, New York, pp. $493-523$, from The Psychosocial Interior of the Family, $3^{\text {rd }}$ Edition, pp. $367-396,1985$.

Kahneman, Daniel, and Dan Lavallo (2002). "Timid Choices and Bold forecasts: A Cognitive Perspective on Risk taking," in Kahneman, Daniel and Amos Tversky (2002). Choices, Values, and Frames, edited by Daniel Kahneman, Amos Tversky. Cambridge University Press, pp. 393-413.

Kirkpatrick, C. and Barrientos, A. (2004). "The Lewis Model after 50 Years," The Manchester School, Vol. 72, No. 6, pp. 679690.

Kogan, Nathan and Michael A. Wallach, (1964). Risk-Taking: A Study in Cognition and Personality, New York, Holt, Rinehart, Winston.

Kowert, Paula and Margaret G. Hermann (1997). "Who Takes Risk? Daring and Caution in Foreign Policy Making,” Journal of Conflict Resolution, 41:5 pp. 611-637.

Leibenstein, H. (1957). Economic Backwardness and Economic Growth, New York, Wiley.

Lewis, W. Arthur. (1954). "Economic Development with Unlimited Supplies of Labor." The Manchester School, volume 22, no. 2, pp. 139-91.

Manning, A. (2003): Monopsony in Motion: Imperfect Competition in Labor Markets, Princeton University Press.

Neher, P. (1971). "Peasents, Procreation and Pensions," American Economic Review, Volume 61, pp. 380 - 389.

Ray, Debraj, (1998). Development Economics. Princeton, NJ: Princeton University Press.

Rosati, F.C. (1996). "Social Security in a non-Altruistic Model with Uncertainty with Endogenous Fertitily," Journal of Public Economics, Volume 60, pp.283 - 294.

Rosenzweig, Mark R. (1977). “The Demand for Children in Farm Households,” Journal of Political Economy, Volume 85, No. 1 (Feb., 1977), pp. 123-146.

Sen, A. K. (1966). 'Peasants and Dualism with or without Surplus Labour', Journal of Political Economy, Volume 74, Number 5, pp. $425-450$.

Sorrentino, R.M, E.C. Hewitt and Raso-Knott P.A., (2005). "Risk-taking in games of chance and skill: individual differences in affective and information value," Journal of Personality and Social Psychology, vol. 62, pp. 522-533.

Stark, O. (1993). "Non-Market Transfers and Altruism," European Economic Review, Volume 37, pp. 1903 - 1940.

Stoner, J. A. F. (1961). A comparison of individual and group decisions involving risk. Unpublished Master's Thesis, Massachusetts Institute of Technology.

Stierlin, Helm (1994). "Centripital and Centrifugal Forces in the Adolescence Sepration Drama," in Gerald Handel and Gail G. Whitchurch Editors, The Psychosocial Interior of the Family, $4^{\text {th }}$ Edition, Aldine de Gruyter, New York, pp.465 - 491. from "Separating Parents and Adolescence," by Helm Stierlin, 1981.

Wang, Xiaobing and Jenifer Piesse, (2013). "The Micro-Foundations of Dual Economy Models," The Manchester School. Volume 81, number 1: pp. 80-101. 


\section{MATHEMATICAL APPENDIX}

The difference between a farm that has to hire non-family workers and a farm with child labor, is how wages are structured. The farm is a firm that maximizes profit using Equation 1, which is a labor intensive profit function:

$$
\text { Maximize } \mathrm{R}(\mathrm{L})-\mathrm{w}(\mathrm{L}) * \mathrm{~L}
$$

where

$$
\begin{aligned}
& \mathrm{L}=\text { labor } \\
& \mathrm{R}=\text { revenue } \\
& \mathrm{w}(\mathrm{L})=\text { wage }
\end{aligned}
$$

Using calculus, the first order maximization condition, with respect to adding new labor, is:

$$
\mathrm{dR} / \mathrm{dL}=(\mathrm{w}+\mathrm{dw} / \mathrm{dL} * \mathrm{~L})
$$

where

$\mathrm{dR} / \mathrm{dL}=\mathrm{MRP}=$ marginal revenue product

$\mathrm{dw} / \mathrm{dL}=$ an increase in wage required to hire the last worker

$\mathrm{dw} / \mathrm{dL} * \mathrm{~L}=$ the additional labor cost due to the increase in wages applied to all other workers

$\mathrm{w}=$ wage of the last worker hired, or the marginal wage

$\mathrm{MLC}=\mathrm{w}+\mathrm{dw} / \mathrm{dL} * \mathrm{~L}=$ marginal labor cost

Equation 2 shows that the last laborer hired requires a wage, w, and that all the existing workers need to have close to the same wage to be satisfied. So each worker needs a change in wage with the cost for that change in wage being $d w / d L * L$. This is why hiring a new worker is so costly since the farmer needs to change everyone's wage every time a new hire is made. Such a monopsony situation is pervasive.

Next, consider a strict hierarchical, family wage, based on age. Each child worker is paid a slight increase in wage contingent upon their age, but where the wages are heterogeneous. Therefore, one child's wage does not change when the number of workers change. Equation 3 shows the profit function:

$$
\text { Maximize } R(L)-\sum \mathrm{w}_{\mathrm{i}}\left(T_{\mathrm{i}}\right)
$$

where

$$
w_{i}=w_{o}+\beta \cdot T_{i}
$$

and where

$$
\begin{aligned}
& \mathrm{R}=\text { revenue } \\
& \mathrm{L}=\text { the number of children (approximately the amount of labor) } \\
& \mathrm{i}=\text { the ith child } \\
& \mathrm{w}_{\mathrm{i}}=\text { wage (or reward) of the } \mathrm{i}^{\text {th }} \text { child for all L children } \\
& \mathrm{w}_{\mathrm{o}}=\text { the initial or base subsistence wage } \\
& \quad \text { (which is low due to economies of scale of family life) } \\
& \beta=\text { the incremental extra reward paid to each child based on age } \\
& \mathrm{T}_{\mathrm{i}}=\text { the age of the ith child }
\end{aligned}
$$


Substituting $\mathrm{w}_{\mathrm{i}}$ in Equation 3, simplifies to Equation 4:

$$
\text { Maximize } R(L)-\mathrm{w}_{\mathrm{o}} \cdot L-\sum\left(\beta \cdot T_{i}\right)
$$

Equation 4 is a profit function where the number of children determines the labor cost. The wage of the oldest child is $\beta \cdot T$. If the child is ten years old then that child receives $w_{o}+10 \cdot \beta$. However, the age of each child is independent of the decision to have another child, so the first order maximization conditions only depend on the base wage as shown in Equation 5:

$$
\begin{aligned}
& \mathrm{dR} / \mathrm{dL}=\mathrm{w}_{\mathrm{o}} \\
& \text { where } \\
& \mathrm{dR} / \mathrm{dL}=\mathrm{MRP}=\text { marginal revenue product } \\
& \mathrm{MLC}=\mathrm{w}_{\mathrm{o}}=\text { marginal labor cost }
\end{aligned}
$$

Equation 5 shows that the last laborer hired, the new child, requires a wage of $\mathrm{w}_{\mathrm{o}}$, but that the other children's wages are independently incremented so that the marginal labor cost is only the new child's wage. That is, the marginal labor cost is not the oldest child's cost, because his wage is independent of how many children there are, but rather, the marginal cost is the subsistence wage of a new baby. The marginal labor cost of a non-family monopsony would be $w+d w / d L * L$, a much higher marginal cost. 